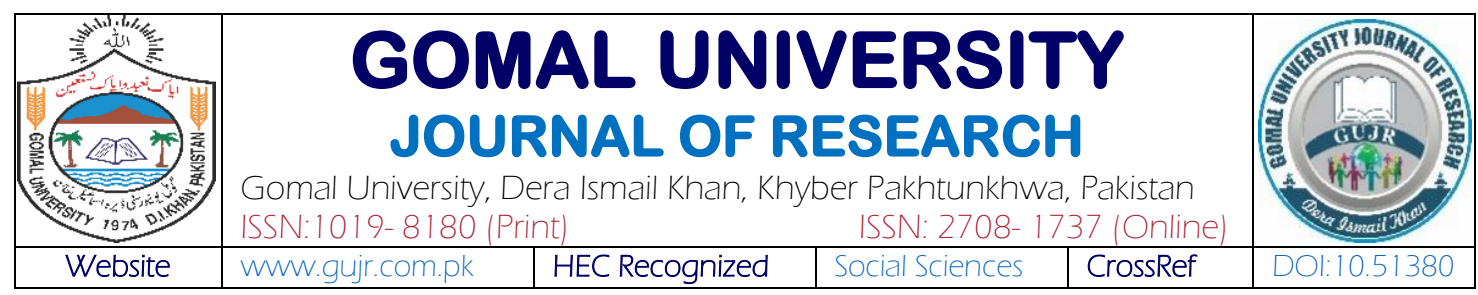

\title{
TEACHERS PERCEPTION ABOUT PROCESS OF TEACHER EVALUATION: A CASE STUDY OF A PRIVATE UNIVERSITY OF LAHORE
}

\author{
Shahid Rafiq' \& Shahzada Oaisar ${ }^{2}$ \\ 'PhD Scholar, Department of Education, University of Education Lahore, Pakistan \\ 2Director Research, University of Education Lahore, Pakistan
}

\begin{tabular}{|c|c|}
\hline KEYWORDS & ABSTRACT \\
\hline $\begin{array}{l}\text { Teachers Evaluation, } \\
\text { Teachers Evaluation } \\
\text { Process, Teachers' } \\
\text { Perception }\end{array}$ & \multirow{3}{*}{ 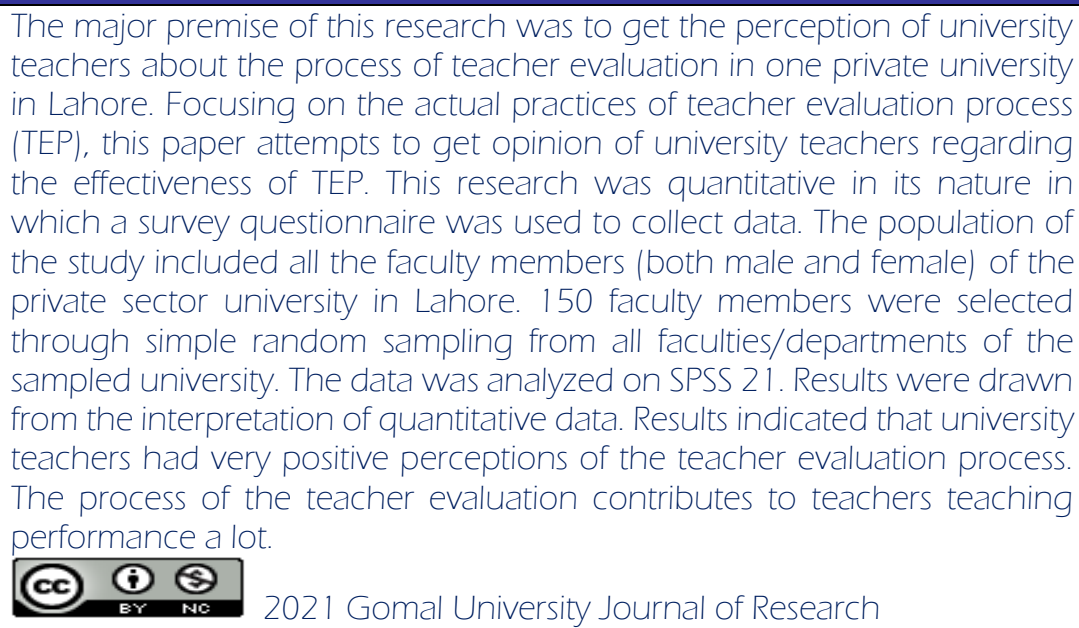 } \\
\hline Article History & \\
\hline Date of Submission: & \\
\hline Corresponding Author & Shahid Rafiq: shahidch525@gmail.com \\
\hline $\mathrm{DOl}$ & https://doi.org/10.51380/gujr-37-03-09 \\
\hline
\end{tabular}

\section{INTRODUCTION}

Evaluation is structured and continuous process of determining the significance, quality, value, or effectiveness of someone's progress or something against existing standards or parameters. Evaluation is key element of every educational society, in overall execution of any institution or system, it is cornerstone. The evaluation may also be described as a systematic inquiry aimed at identifying a program's nature or a person's performance evaluation or something in a target (Skedsmo \& Huber, 2018). Although evaluation has been a regular feature of everyday life in educational institutions, it has become the policy matter and a tool for quality assurance and development for higher education institutions at national and international levels. The higher education sector, worldwide, has become much more concerned about developing evaluation policies where much weightage is given in establishing the units, departments, or organizations skilled and specialized in conducting the teacher evaluations (Moran, 2017). In this connection, 
with establishment of Pakistan's Higher Education Commission (HEC), it was recognized that specific quality assurance department must be set up for a systematic academic assessment and evaluation.

In this regard, in 2004, HEC-Pakistan constituted the Quality Assurance Agency (QAA) at state and federal level, followed by Quality Enhancement Cells (QECs) at institutional level (HEC, 2015). In a step-by-step process, quality assurance agency formed Quality Enhancement Cells in public and private sector universities to conduct program evaluation over self-assessment. Simultaneously, along with other feedback tools, the quality assurance agency also introduced teacher evaluation and course evaluation into program evaluation (Ali \& Hussain, 2018). These teacher evaluation methods focused on the teacher's performance in the classrooms, which are teacher self-assessment, peer evaluation, and student evaluation of the teachers in the concerned instiutions. In this drive, Qazi, Niazi and Inam (2019) described that the QECs are responsible for conducting and evaluating periodic teacher evaluation of both the full-time and part-time faculty members, along with several other functions. For this purpose, the QECs conduct this activity through the teacher self-appraisal, evaluation through the heads of the department or dean, and student evaluation of the teachers, by following the criteria and guidelines given by HEC.

This process of evaluating teaching effectiveness serves two essential purposes, i.e., creating awareness that excellence is cornerstone of higher education and establishes that teaching has the central position to ensure quality (Chalmers \& Hunt, 2016). Many researchers argue that teachers have different perceptions about process of teacher evaluation (Flores, 2018). Some take this process very seriously and others take it as formal activity. Flodén (2017) reported that the majority of teachers do have some faith in the teacher evaluation process and they consider it a powerful tool to get information about their pedagogical practices. Many teachers admitted that they improved their teaching strategies according to results of these evaluations regarding their teaching styles (Darling-Hammond, 2017). The findings reported by study of (Donaldson \& Papay, 2014) stated that teacher evaluation is the most authentic and accurate source for measuring teachers' teachings capabilities. Callahan and Sadeghi (2015) claimed that teacher evaluation results are important for Deans and Heads of Department of any university and they use it for making value judgment for reward/ dismissal and evaluating teaching quality of their faculty.

Kaymakamoglu (2018) reported that the process of the teacher evaluation should be teachingscentered only. On the contrary, some researchers described that teacher evaluation is the futile exercise and they are of the view that usually teachers do not like this evaluation system and the question that how only a few questions asked in feedback form can become base of judgment about their teaching performance (Boysen et al., 2014; Elstad, Lejonberg \& Christophersen, 2015; Choi \& Park, 2016; Lillejord, Elstad \& Kavli, 2018). These researchers also claim that evaluation results can be used against someone or can be misinterpreted due to some personal/ political influence, and misinterpretation always results in indicating/showing poor teaching performance of a teacher. Kimball, Rainey, and Mueller (2016) revealed in a study that the aim of teacher evaluation should not be to target teachers. In this regard, they further reported that sometimes this activity is used against someone for the workplace conflicts and grudges in the instiutions. The researcher found this topic worth researching in different contexts and; hence 
the present study is about to know the teachers' perceptions about the process of the teacher evaluation.

\section{LITERATURE REVIEW}

The teacher evaluation is most actively sought in higher education to sustain quality, especially in private institutions. Private higher education systems have stricter mechanism of accountability and performance appraisal for their teachers (faculty), and this adds the moral and political dimension to the teacher evaluation process (Bastian, Patterson \& Pan, 2018). It is mandatory for all higher education institutions (whether public or private) to maintain an active quality assurance system that conducts internal and external quality assurance to report to the Higher Education Commission (HEC). Teacher evaluation is a constant check which is imposed upon faculty to maintain the quality of teaching-learning. Thus, it has a huge impact on perceptions of teachers (Robertson-Kraft \& Zhang, 2018). Evaluation in education always varies in different context. What may seem suitable in one context may not be appropriate in another context. The practices used for teacher evaluation may differ from instance to instance or from one university to another what is suitable for one university may be less suitable for another. Usmani and Khatoon (2018) stated that as per contemporary evaluation practices in Pakistan, it is known that teacher evaluation was conducted at institutional level only, and even that was not systematic and aligned.

Teacher evaluation is least formal in Pakistani context, and in the past, it had not been conducted in many public sector universities, but now HEC has made it the mandatory feature of the teaching and learning process. In this connection, the teacher evaluation process is significant to enhance the quality of teaching and worth of the institute because teachers' performance is directly related to student achievement, so this can only be ensured by the use of appropriate teacher evaluation process and tools. In this regard, by the end of the 2oth century, teacher evaluation was long ignored unspecified and unclear policy features and controversial issues, but now it has become most popular and hot-topic in the education sector (Beauchamp, 2015). In this linking, a well-known evaluation process may empower teachers with teaching tactics, promote self-reflection and increase their performances in instiutions (Heritage, 2017). Every institution needs to keep its employee's performance at its best. Likewise, higher management in universities always actively looking for new ways of evaluating and improving their faculty members. Value-able feedback can be given to teachers based on evaluation results (Bichi, 2017). In this regard, this process made it easier to make decisions like promotions or dismissals of teachers.

Literature reveals that a well-designed teacher evaluation mechanism can lead to the desired quality assurance results that institute wants to achieve (Darling-Hammond, Hyler \& Gardner, 2017). It was also observed that the teachers show resistance to accept this evaluation process and they claimed that techniques and tools used for this process are ineffective and outdated (Muthuri, Momanyi \& Nduku, 2019). In the education system of Pakistan, teacher evaluation is less concentrated (Khan, Khan, Hussain \& Shaheen, 2017). Teacher evaluation is least formal in the Pakistani context, and in past, it had not been conducted in many public sector universities, but now HEC has made it the mandatory feature of the teaching and learning through Quality Enhancement Cells (QEC). The teachers in Pakistan are evaluated by QEC on the Performance Evaluation Report (PER). It is rapidly strengthening in the system, but the problem of a dense mechanism still there. As a result, universities are taking measures to evaluate the quality of 
teaching faculty as per the guidelines provided by HEC. In this regard, to ensure the teacher success, several countries around the world are adopting more robust assessment techniques and tools.

Teacher participation in the preparation and design of strategies and tools appears to have a better attitude towards evaluation process (Golding \& Adam, 2016). Many researchers agree that a well-structured evaluation process do provides sufficient information about the ability of a teacher and can be used for assessing necessary skills in a teacher (Smith, Cook, and Buskist, 2011; Galbraith, Merrill, and Kline, 2012; Boysen et al., 2014). Flodén (2017) reported that the majority of teachers do have some faith in the teacher evaluation process and they consider it a powerful tool to get information about their pedagogical practices. Many teachers admitted that they improved their teaching strategies according to the results of the teacher evaluation (Boysen et al., 2014; Hammond, 2017; Flores, 2018). Teachers use it for pedagogical growth purposes while administration uses it to assess teaching quality of their faculty and for decision making regarding promotion and tenure of teachers (Tuytens \& Devos, 2017; Lillejord \& Børte, 2020). Researchers reported many teachers just take this process as formality and as routine practice. There are a lot of perceptions about this process therefore, it is valuable to analyze this area.

After the extensive literature, the researcher found that in Pakistani context teacher evaluation has been usually studied at school level, and number of studies addressing this phenomenon at the university level are very few (Khan, Khan, Hussain \& Shaheen, 2017; Faremi, 2017). In this connection, teacher evaluation is merely a formality in public sector universities in Pakistan, though, in private sector universities, it is a matter of promotion, raise in salary, or demotion. The researcher found it curious and value-seeking and decided to explore this phenomenon from a different angle; hence, this research seeks to know the teacher's perceptions about the process of teacher evaluation of a private university of Lahore. The researcher had worked in different private universities in Pakistan and closely observed the teacher evaluation process there. It was observed that many teachers do not like this process, many teachers take this process as a formality, some take it seriously and some were afraid of this process. It was also observed that this process to be taken as a political activity. The university teachers are often found claiming that they did not get desired grade in their appraisal, yet they had performed well in all the assigned tasks (Pereira \& Flores, 2016). So, researcher decided to research this area.

\section{Problem Statement}

The teachers are concerned about teacher evaluation process, whereas some accept this process as to improve teaching quality and performance and consider it a futile practice. Numerous teachers are anxious that teacher evaluation process and tools are vague and time-consuming, and they also claimed that teacher evaluation does not have any impact on their performance, it is just a useless process (Ellahi, 2018). The evaluation criteria generate tension and anxiety among teachers in terms of how evaluation results will affect teachers and their performance. The teacher evaluation process and practices have a massive effect on quality of teaching and learning. Ali (2019) reported that only a few researches done at higher level, but not specifically at the private university level to check the perceptions of teachers about the teacher evaluation process. So, this study will analyze perceptions of university teachers about teacher evaluation process. 


\section{Objective of Study}

The objective of this research was to find out the validity and reliability of the process of teacher evaluation in the one private university in Lahore, Pakistan. Therefore, the main aim of this study was: To measure the university teacher's perceptions about the process of the teacher evaluation.

\section{Research Question}

What are the university teachers' perceptions about the whole process of teacher evaluation in institution?

\section{Significance of Study}

It may provide valuable information on the perceptions of teachers about the process of teacher evaluation at university level. It may serve as resource material for others who want to research the related areas. Precisely, it will guide university's management to develop a better evaluation policy and mechanism for their teachers' evaluation. It may provide information and guidelines to university administration to modify the criterion to assess quality teacher performance. This paper may provide a pathway for potential scholars of this field to check, verify and recommend various aspects of this research. The study would explore university teacher's perceptions about how process of teacher evaluation is being conducted in private universities and how it can be improved.

\section{Figure 1}

Model of Teacher Teaching Performance

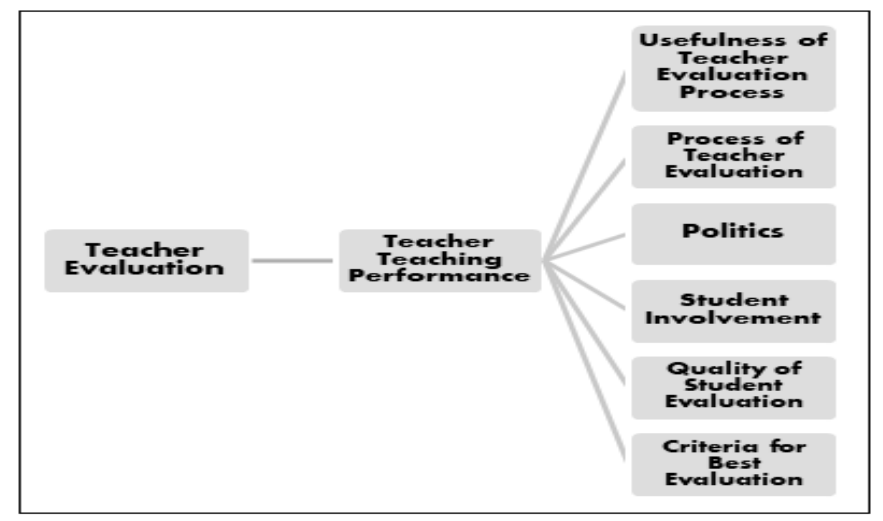

\section{RESEARCH METHODOLOGY}

The reasoning behind adherence to one research approach over another is provided by research paradigms. The methods used by a researcher are determined by philosophical and functional needs because it's a journey from ideas to deeds. The researcher used the positivism paradigm for this study. The positivism theory is based on perceptions, and the main source of actual information is the perception by the senses. The positivists believe that only facts that can be confirmed by scientific proof can be called truths. This research was quantitative in its nature in which a survey questionnaire was used to collect data. Many academics believe that a survey is an ideal tool for gathering opinions/conceptions (Ary, Jacobs, Irvine \& Walker, 2018). As indicated by Queirós, Faria and Almeida (2017) that the quantitative work depends on landing 
at speculations by obtaining, enlistment, specifically analyzing and dissecting cases. Ultimate focus of survey research is to collect data from a sample of target population using statement or scale format.

It is also the most used method in educational research along with the most suitable strategy to collect data from a large population (Lazar, Faciu, Mata \& Lazar, 2016). The population of this study consisted of all the faculty members from the one private sector university in Lahore. The sampled university had 10 faculties/departments, thus covering the Faculty of Information and Technology, Faculty of Management Studies, Faculty of Engineering, Faculty of Arts and Social Sciences, Faculty of Pharmacy, Faculty of Life Sciences, Faculty of Sciences, Faculty of Media and Communication Studies, Faculty of Law, and English Language Center. From 10 faculties/ departments of one private university, scholar used simple random sampling. The researcher selected 15 faculty members from all faculties/departments and a total of 150 faculty members selected.

Table 1

Sampling Frame

\begin{tabular}{llcc}
\hline SN & Name of Faculty /Department & Total Faculty & Randomly Selected \\
\hline 1 & Faculty of Information and Technology & 100 & 15 \\
2 & Faculty of Faculty of Management Studies & 105 & 15 \\
3 & Faculty of Engineering & 95 & 15 \\
4 & Faculty of Arts and Social Sciences & 36 & 15 \\
5 & Faculty of Pharmacy & 43 & 15 \\
6 & Faculty of Life Sciences & 52 & 15 \\
7 & Faculty of Sciences & 31 & 15 \\
8 & Faculty of Media \& Communication Studies & 77 & 15 \\
9 & Faculty of Law & 24 & 15 \\
10 & English Language Center & 39 & 15 \\
\hline \multicolumn{2}{l}{ Total } & 602 & 150 \\
\hline
\end{tabular}

\section{Instrumentation}

The items of survey questionnaire were made after extensive literature review. The instrument consisted of thirty-two (32) items comprising seven factors which included usefulness, process, politics, student involvement, quality of student evaluation, criteria for best evaluation, teacher teaching performance. The items were individually measured on a 5-point Likert type, $1=$ strongly agree, 2 = agree, $3=$ undecided, $4=$ disagree, and $5=$ strongly disagree. There were four opened questions. The validity of instrument was determined by expert opinion and reliability of self-made instrument was measured over Cronbach's Alpha method, and it was .723. The data were analyzed over SPSS 21. Factor analysis and linear regression were methods used to analyze data.

\section{DATA ANALYSIS}

The data was collected using survey questionnaire approach, and results of teachers' perception of the teacher evaluation process were analyzed and driven using the Statistical Package. The statistical calculations described university teachers' perceptions regarding process of teacher evaluation. 


\section{Demographic Information}

This section presents demographic information of sampled population in terms of gender, age, qualification, designation, experience. Table 2 offers information about gender of respondents which shows that (69.33\%) of the faculty members were males while females were 30.67 percent. Nearly the respondents (47.33\%) were between the ages of 25-35 years and nearly (35.33\%) respondents were $36-45$ years of age, while only $17.34 \%$ were 46 years and above. Table 2 further provides the information regarding the qualification of faculty members. Nearly 59.33 percent of respondents were M. Phil/MS qualification and about 40.67\% faculty members were Ph.D. qualification, and there was no respondent at Masters qualification. Further, the table provides the designation of respondents from which 45.33 were Lecturers, nearly $32.67 \%$ were Assistant professors, about $16 \%$ respondents were Associate professors and only $6 \%$ of respondents were full Professors. Moreover, table 1 also provides the experience of the respondents, from which 59.33 percent were 1-10 years of experience, nearly 28.67 of the respondents were 11-20 years of experience and only 12 percent of the respondents were the experience of the 21 years and above.

\section{Correlation Analysis}

Table 3 shows that Pearson product-moment correlation was run to test variables. From the correlation table, it can be seen that usefulness of teacher evaluation process, process of teacher evaluation, politics, student involvement, student evaluation quality, criteria of best evaluation, and teacher teaching performance have a positive strong correlation with each other $(\mathrm{n}=100$, $\mathrm{p}<.000$ ). The teacher evaluation process was found to be significantly correlated with Politics, Student involvement, and proposed improvement $\left(\mathrm{r}=0.497^{* *}, 0.394^{* *}, 0.325^{* *}\right)$, proposed improvement is correlated with politics and student involvement $\left(\mathrm{r} .305^{* *}, .390^{* *}\right)$ quality of Student Evaluation with criteria of best evaluation ( $\left.\mathrm{r} \cdot 359^{* *}\right)$. Positive but week correlation of Politics was found with the Process of teacher evaluation and student involvement (0.267**, $\left.0.269^{* *}\right)$.

\section{Table 3}

\section{Correlation Matrix}

\begin{tabular}{|c|c|c|c|c|c|c|}
\hline & POT & POL & STI & QSE & CBE & TTP \\
\hline Usefulness of TEP (UOT) & .196 & $.497^{* *}$ & $.394^{* *}$ & .090 & -.011 & $.325^{* *}$ \\
\hline Process of TE (POT) & 1 & $.267^{* *}$ & -.078 & .188 & $.199 *$ & .073 \\
\hline Politics (POL) & & 1 & $.269 * *$ & .026 & -.040 & $.305^{* *}$ \\
\hline Student Involvement (STI) & & & 1 & .082 & -.085 & $.390^{* *}$ \\
\hline Quality of Student Evaluation (QSE) & & & & 1 & $.359^{* *}$ & .066 \\
\hline Criteria of Best Evaluation (CBE) & & & & & 1 & .027 \\
\hline Teacher Teaching Performance (TTP) & & & & & & 1 \\
\hline
\end{tabular}

\section{Regression Analysis}

Multiple regression was applied to evaluate the teachers' teaching performance with the help of the usefulness of the teacher evaluation process, process of teacher evaluation, politics, student involvement, quality of student evaluation, and criteria of best evaluation. Initial analysis was conducted to ensure no violation of the assumptions of normality, linearity, multicollinearity, 
and homoscedasticity. The usefulness of the teacher evaluation process, the process of teacher evaluation, politics, student involvement, quality of the student evaluation, and criteria of best evaluation have explained $23.5 \%$ of the variance in teacher teaching performance. The overall model was significant. Moreover, the usefulness of the teacher evaluation process, the process of teacher evaluation, and criteria of best evaluation politics were significant predictor while student involvement and quality of student evaluation were not significant predictor of teacher teaching performance. In addition to this, politics was a negative predictor of teacher teaching performance.

\section{Table 4}

Predicting the Teachers' Teaching Performance

\begin{tabular}{lcccc}
\hline & $\mathrm{B}$ & $\mathrm{SE}$ & $\beta$ & P (significance) \\
\hline Usefulness of TEP & .003 & .002 & .172 & .002 \\
Process of TE & .523 & .440 & .159 & .004 \\
Politics & .534 & .444 & -.102 & .001 \\
Student Involvement & .000 & .002 & .015 & .917 \\
Quality of Student evaluation & -.171 & .513 & .017 & .739 \\
Criteria of Best Evaluation & .170 & .051 & .129 & .001 \\
\hline
\end{tabular}

$\mathrm{R} 2=.235$

Note: $\mathrm{TEP}=$ Teacher Emulation Process, $\mathrm{TE}=$ Teacher Evaluation

Result for question that if teacher constantly gets poor evaluation results of his/her teachings, what would be suitable actions for it, shows that out of 150 respondents 79 teachers answered that teacher should be directed to receive instruction in effective teaching, 25 teachers replied that teacher should be fired, 17 teachers said that allow teacher to perform research but not to teach, 12 respondents said that there should be cut in teachers' pay, 11 teachers reported that teacher should not be allowed to teach course again while 6 faculty members said for demotion of teacher.

\section{Figure 2}

If Teacher Constantly Gets Poor Evaluation Results of Teachings

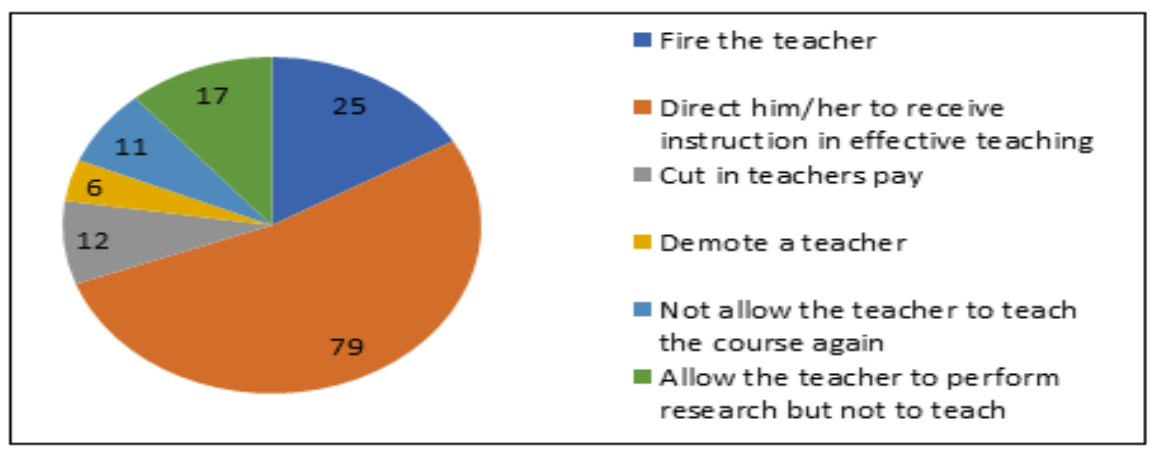

The result for question that teacher evaluations are used to, shows that out of 150 respondents 71 faculty members shared that teacher evaluation is used to improve teacher teaching method/ style, 39 teachers answered that it is used to improve courses, 27 faculty replied that it is used 
to promote senior/tenure teacher while only 13 teacher said that it is used to give raise in pay of teachers.

\section{Figure 3}

Teachers' Evaluations are Used to

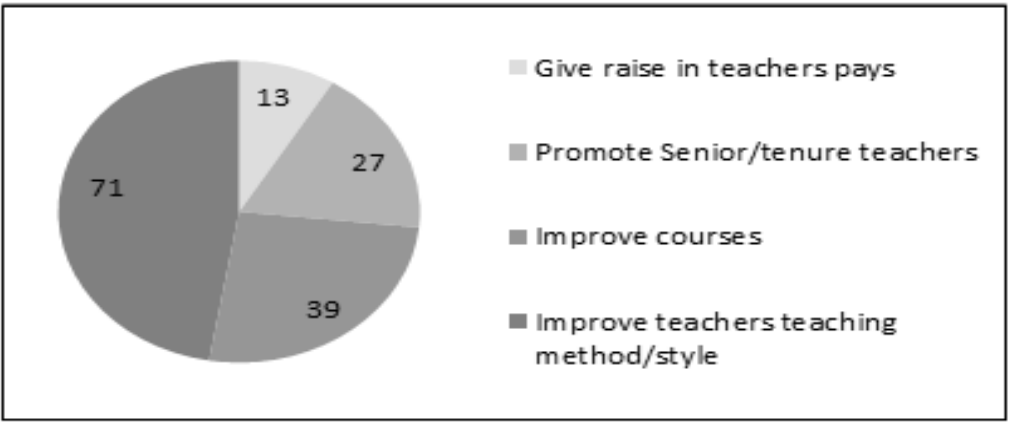

The result for question that teachers use evaluations feedback to improve their course, shows that out of 150 respondents 53 teacher said that they use evaluation feedback for making changes to meet students' need, 51 faculty members answered that teachers use evaluation feedback for making topics relevant, interesting, challenging or fun, while only 46 faculty members reported that teachers use evaluation feedback for adopting students' ideas, changes in grading, addition of new topics.

\section{Figure 4}

Teachers Use Evaluation Feedback to Improve their Courses

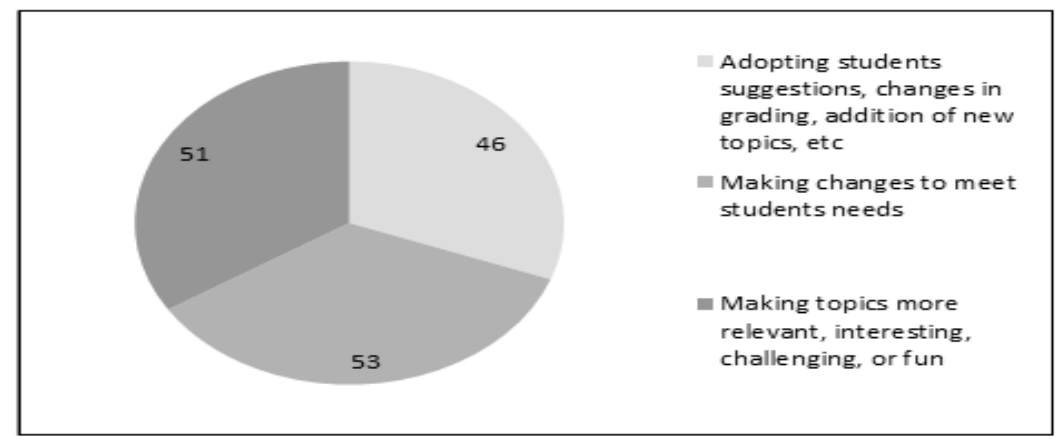

The result for the question that among most valid criteria for evaluating a teacher's teaching ability are, out of 150 respondents 44 faculty members said that among most valid criteria for evaluating a teacher's teaching ability is challenging teachers to think critically about issues, 32 teachers replied for statement being an "expert" on subject s/he is teaching, 23 teachers support statement for being organized, clear, and command thorough in his/her lectures, 21 teachers responded to statement being an interesting speaker who holds students' attention, 19 teachers answered the statement using a fair system for examinations and evaluating students while only 11 teachers described the statement being a "warm" person who encourages and motivates students. 


\section{Figure 5}

Among Most Valid Criteria for Evaluating a Teacher's Teaching Ability are

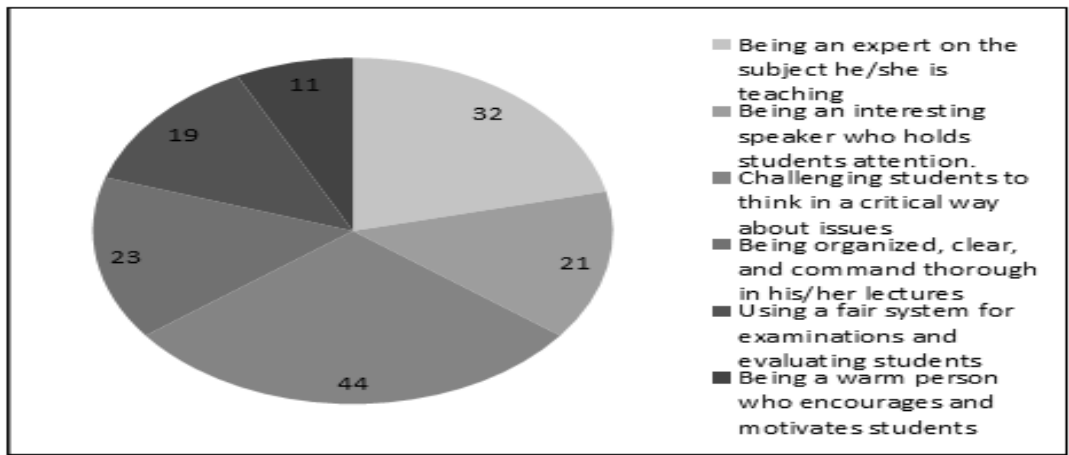

\section{DISCUSSION}

The main objective of this study was to get perceptions of university teachers about the process of teacher evaluation in one private university of Lahore. The analysis of the study was based on the following factors: Usefulness of TEP, Process of TE, Politics, Student involvement, Quality of student evaluation, Criteria of best evaluation, Teacher Teaching Performance. This shows that university teachers consider that the teacher evaluation process is a useful activity that is conducted in a fair, unbiased, and transparent manner by the university administration. These results were also supported through the studies titled "impact of student feedback on teaching in higher education" conducted by Flodén (2017) and Hammond (2017). The results of data showed that teachers want this process of teacher evaluation to be teaching-centered rather than teacher-centered. These findings were also supported by the study titled "learning-centered teacher evaluation in Wisconsin" carried by Kimball, Rainey \& Mueller (2016). These results emphasized that teachers want to be assessed as teaching of a university teacher, instead of the personal characteristics or personality of a teacher. Moreover same results were supported a study "teachers' beliefs, perceived practice and actual classroom practice in relation to traditional (teacher-centered) and constructivist (learner-centered) teaching" conducted by Kaymakamoglu (2018).

Teachers showed positive responses regarding the process that they take teacher evaluation very seriously and upgrade their teachings practices as per the results of teacher evaluation. Teachers also agreed that appropriate use of teacher evaluation process can easily differentiate between good and poor teaching. Similar findings were also reported by Bichi, (2017), Heritage (2017) and Flores (2018) in their studies. The findings of this study emphasized that the results of teacher evaluation are very much helpful for the low-performing teachers to improve their teachings. In thic connection, in another study, almost similar results were reported in a study titled "teacher evaluation: the need for valid measures and increased teacher involvement" by Skedsmo \& Huber (2018). It is highlighted by the findings of this study that if a person repeatedly got poor evaluation results, he/she should be given instructions to get training or instructions about effective teachings; similar findings were revealed by Boysen et al., (2014). The findings of the current study pointed that teacher evaluation is the most valid criteria for evaluating a teacher's teaching abilities. Almost similar results were reported in a study titled 
"teacher evaluation for accountability and development" by (Donaldson \& Papay, 2014) in their study.

\section{CONCLUSION}

It is concluded that teachers have a positive perception of teacher evaluation process conducted in their university. Teachers are often unaware of the purposes of faculty teaching assessments, and as a result, they can see the procedure as a pointless activity with little effect. The teachers in our studies were generally aware that one aim of teaching evaluation process was to improve teaching and strengthen course content. Also, they were unsure, whether those evaluations were used in deciding on incentives and rewards. Such feedback should necessarily be discussed with teachers so that they are well aware of the implications of their evaluations. Teachers agree that teaching evaluations are significant, helpful and that they are taken seriously. Despite their doubts regarding whether management takes them seriously or not. It is also concluded that the process of teacher evaluation contributes a lot to teachers teaching performance, but it all depends on effectiveness of teacher evaluation process.In comparison to the negative "myths," results of this study show that teacher evaluations are primarily effective credible and unchanged by perceived biases. If teachers were aware that their evaluations would have an influence, one might obtain much credible and accurate results from teacher evaluation like incentives, rewards and bonuses.

\section{Recommendations}

1. This study was conducted at one private university level, future researchers may conduct it in public sector.

2. The process of teacher evaluation should be teachings-centered rather than teachertargeted.

3. The process of teacher evaluation should be free from any kind of politics, influence, or pressure.

4. The purpose/outcome of teacher evaluation should also be communicated with all other teachers.

5. Teacher evaluation may be conducted in fair, unbiased and transparent manner by university administration.

\section{REFERENCES}

Ali, H., \& Hussain, B. (2018). Analysis of Teaching Evaluation Practices in Universities of Pakistan at Policy Level: Implications for Stakeholders. Pakistan Journal of Social Sciences, 38(2).

Ary, D., Jacobs, L. C., Irvine, C. K. S., \& Walker, D. (2018). Introduction to research in education. Cengage Learning.

Bastian, K. C., Patterson, K. M., \& Pan, Y. (2018). Evaluating teacher preparation programs with teacher evaluation ratings: Implications for program accountability and improvement. Journal of Teacher Education, 69(5), 429-447.

Beauchamp, C. (2015). Reflection in teacher education: issues emerging from a review of current literature. Reflective Practice, 16(1), 123-141.

Bichi, A. A. (2017). Evaluation of teacher performance in schools: Implication for sustainable development goals. Northwest Journal of Educational Studies, 2(1), 103-113. 
Boysen, G. A., Kelly, T. J., Raesly, H. N., \& Casner, R. W. (2014). The (mis) interpretation of teaching evaluations by college faculty and administrators. Assessment \& Evaluation in Higher Education, 39(6), 641-656.

Callahan, K., \& Sadeghi, L. (2015). Teacher Perceptions of the Value of Teacher Evaluations: New Jersey's ACHIEVE NJ. International Journal of Educational Leadership Preparation, 10(1), 46-59.

Chalmers, D., \& Hunt, L. (2016). Evaluation of teaching. HERDSA Review of Higher Education, 3, 25-55.

Choi, H. J., \& Park, J. H. (2016). An analysis of critical issues in Korean teacher evaluation systems. Center for Educational Policy Studies Journal, 6(2), 151-171.

Donaldson, M. L., \& Papay, J. P. (2014). Teacher evaluation for accountability and development. In Handbook of research in education finance and policy (pp. 190-209). Routledge.

Ellahi, A. (2018). The Academia. Retrieved from Academia: Retrieved http: //academiamag. com/teacher-evaluation-forms-pak-universities/.

Elstad, E., Lejonberg, E., \& Christophersen, K. A. (2015). Teaching evaluation as a contested practice: Teacher resistance to teaching evaluation schemes in Norway. Education Inquiry, 6(4), 27850.

Faremi, M. F. (2017). An assessment of teacher retention and job security in private secondary schools in Ogun state, Nigeria. Bulgarian Journal of Science and Education Policy, 11(2), 279-293.

Flodén, J. (2017). The impact of student feedback on teaching in higher education. Assessment \& Evaluation in Higher Education, 42(7), 1054-1068.

Flores, M. A. (2018). Teacher evaluation in Portugal: persisting challenges and perceived effects. Teachers and teaching, 24(3), 223-245.

Galbraith, C. S., Merrill, G. B., \& Kline, D. M. (2012). “Are Student Evaluations of Teaching Effectiveness Valid for Measuring Student Learning Outcomes in Business Related Classes? A Neural Network and Bayesian Analyses.” Research in Higher Education 53: 353-374. doi:10.1007/s11162-011-9229-0.

Golding, C., \& Adam, L. (2016). Evaluate to improve: useful approaches to student evaluation. Assessment \& Evaluation in Higher Education, 41(1), 1-14.

Hammond, D. L. (2017). Teacher education around the world: What can we learn from international practice?. European journal of teacher education, 40(3), 291-309.

Hammond, D. L., Hyler, M. E., \& Gardner, M. (2017). Effective Teacher Professional Development.

Heritage, M. (2017). Changing the assessment relationship to empower teachers and students. In Preparing Students for College and Careers (pp. 153-164). Routledge.

Higher Education Commission (2015). Institutional performance evaluation process Manual for six standards. Islamabad: HEC Quality Assurance Agency.

Higher Education Commission (2015). National Qualifications Framework of Pakistan 2015 (Draft). Islamabad.

Kaymakamoglu, S. E. (2018). Teachers' Beliefs, Perceived Practice and Actual Classroom Practice in Relation to Traditional (Teacher-Centered) and Constructivist (Learner -Centered) Teaching (Note 1). Journal of Education and Learning, 7(1), 29-37.

Khan, G., Khan, A., Hussain, S., \& Shaheen, N. (2017). Teacher evaluation: global perspectives and lessons for Pakistan. Dialogue (Pakistan), 12(3), 49-56. 
Kimball, S. M., Rainey, K. M., \& Mueller, M. (2016). Learning-centered teacher evaluation in Wisconsin. In Handbook of research on professional development for quality teaching and learning (pp. 618-633). IGI Global.

Lazar, I., Faciu, M. E., Mata, L., \& Lazar, G. (2016). Strengths and Limitations of Quantitative Research Applied in the Educational Sciences. In International Conference The Future of Education, 6th edition, Florence, Italy (Vol. 30, pp. 240-244).

Lillejord, S., \& Børte, K. (2020). Trapped between accountability and professional learning? School leaders and teacher evaluation. Professional development in education, 46(2), 274-291.

Lillejord, S., Elstad, E., \& Kavli, H. (2018). Teacher evaluation as a wicked policy problem. Assessment in education: Principles, policy \& practice, 25(3), 291-309.

Moran, R. M. (2017). The impact of a high stakes teacher evaluation system: Educator perspectives on accountability. Educational Studies, 53(2), 178-193.

Muthuri, A. M., Momanyi, M., \& Nduku, E. (2019). Challenges Encountered in Lecturers' Performance Appraisal in Public Technical Training Institutions in Nairobi Region, Kenya. Journal of African Interdisciplinary Studies, 3(8), 190-210.

Pereira, D. R., \& Flores, M. A. (2016). Conceptions and practices of assessment in higher education: A study of Portuguese university teachers. Revista Iberoamericana de Evaluación Educativa, 9(1), 9-29.

Qazi, T. F., Niazi, A. A. K., \& Inam, S. (2019). Evaluating Research Performance of Leading Pakistani Universities: A Grey Relational Analysis. Journal of Research \& Reflections in Education (JRRE), 13(2).

Queirós, A., Faria, D., \& Almeida, F. (2017). Strengths and limitations of qualitative and quantitative research methods. European Journal of Education Studies.

Robertson-Kraft, C., \& Zhang, R. S. (2018). Keeping great teachers: A case study on the impact and implementation of a pilot teacher evaluation system. Educational Policy, 32(3), 363-394.

Skedsmo, G., \& Huber, S. G. (2018). Teacher evaluation: the need for valid measures and increased teacher involvement. Educational Assessment, Evaluation and Accountability, 30(1), 1-5.

Smith, D. L., P. Cook, and W. Buskist. 2011. "An Experimental Analysis of the Relation between Assigned Grades and Instructor Evaluations.” Teaching of Psychology, 38 (4): 225-228. doi:10.1177/0098628311421317.

Tuytens, M., \& Devos, G. (2017). The role of feedback from the school leader during teacher evaluation for teacher and school improvement. Teachers and Teaching, 23(1), 6-24.

Usmani, M. A., \& Khatoon, S. (2018). Impact of program evaluation through self-assessment in higher education institutions in Pakistan. Contemporary Educational Researches Journal, 8(4), 134-141. 